\title{
THE EFFECT OF LOCUS OF CONTROL IN RESPONSIBILITY AMONG PARTICIPANTS WITH TRAUMATIC EVENT HISTORY*
}

\author{
Merve Topcu ${ }^{1}$, Deniz Köroğlu ${ }^{1}$, Yusuf Coşku İnceler ${ }^{1}$, \& Faruk Gençöz ${ }^{2}$ \\ ${ }^{1}$ Department of Psychology, Çankaya University (Turkey) \\ ${ }^{2}$ Department of Psychology, Middle East Technical University (Turkey)
}

\begin{abstract}
Individuals' causal attributions between their behavior and a reward determine their future behaviors (LoC). When individual perceive limited control over an action, then the behavior appraised as a result of luck, and fate, as under the control of powerful others, or as unpredictable. It is called external LoC. When the event is perceived as contingent upon his/her behavior, it is internal LoC. Traumatic events are defined as disruptive to the daily routine, develop suddenly and unexpectedly, create horror, anxiety and panic, and disturb the process of making sense of the world. However, after traumatic event exposure it is possible to show psychological improvement, which is entitled as posttraumatic growth. Positive correlation between posttraumatic growth and responsibility has been found in the literature. Responsibility defined as individual's fulfilment of antecedents and consequences of their emotions, cognitions, and behaviors. It was thought that understanding the responsibility could be essential on the way through posttraumatic growth. The role of LoC in responsibility among people with traumatic event history was examined. A cross-sectional paper-pencil format study conducted with 139 participants who reported at least one traumatic event exposure included in the analysis. Informed consent, socio-demographic form, the Positive (PA) and Negative Affect (NA) Scale, the LoC Scale, the Social Desirability Inventory, and the Responsibility Scale were given to the participants. Correlational analysis shows that responsibility was positively correlated with PA for last six months and social desirability. The responsibility was negatively correlated with NA for last six months and belief in an unjust world. 2-stepped hierarchical regression analysis run to examine the role of $\mathrm{LoC}$ in the prediction of responsibility. Social desirability, PA and NA were entered in the first step. Significantly correlated belief in an unjust world dimension of LoC with responsibility entered in the second step. Results demonstrated that belief in an unjust world significantly predicted responsibility when controlled for social desirability and PA and NA. That is, those who believe in that world is an unjust place may think, feel or act responsibly more. And also, thinking, feeling or acting responsibly may be appraised as protective against feelings of failure, guilt or shame, fear of punishment, uncertainty and being victim of an uncontrolled event. Eventually this protection may be rewarding. On the way through posttraumatic growth, belief in an unjust world and responsibility may be influential factors especially on therapeutic process with individuals with traumatic event history.
\end{abstract}

Keywords: Trauma, growth, locus of control, responsibility.

\section{Introduction}

Individuals' causal attributions to the relationship between their behavior and a reward determine their future behaviors. This is called the locus of control (LoC). When individuals perceive limited control over an action, then the behavior appraised as a result of luck, and fate, as under the control of powerful others, or as unpredictable, called external LoC. When the event is perceived as contingent upon his/her behavior, it is internal LoC (Rotter, 1966). Traumatic events are defined as disruptive to the daily routine, develop suddenly and unexpectedly, create horror, anxiety and panic, and disturb the process of making sense of the world (APA, 2013). However, after traumatic event exposure, it is possible to show psychological improvement, which is entitled as posttraumatic growth (Tedeschi \& Calhoun, 1995; 2004). Positive correlation between posttraumatic growth and responsibility has been found (Topcu, 2016). Responsibility is defined as an individual's fulfillment of antecedents and consequences of their emotions, cognitions, and behaviors (Topcu, Öge, \& Gençöz, 2018; Topcu, 2016). It was thought that understanding

*Additional information: The study presented in this manuscript is part of the doctorate thesis of the first author. 
the responsibility could be essential on the way through posttraumatic growth. The role of the LoC in responsibility among people with traumatic event history was examined.

The aim of the current paper is to assess the role of the LoC in the prediction of responsibility while controlling the effects of social desirability and positive (PA) and negative (NA) affect for last six months in a sample of individuals with at least one traumatic event history. It was hypothesized that when social desirability and PA and NA for last six months were controlled, significant association between the LoC and responsibility are still expected.

\section{Methods}

\subsection{Participants}

139 participants who reported at least one traumatic event history included in the study to examine the relationship of responsibility and dimensions of the LoC. Age of the participants varied between 18 to 52 years $(\mathrm{M}=32.86, \mathrm{SD}=12.55) .25 .2 \%(n=35)$ of the participants are male, $74.8 \%(n=104)$ of them are female. SD, PA and NA for last 6 months and the LoC group mean scores compared across gender via Mann-Whitney $U$ test. Though the gender ratio was in favor of females, Bonferroni correction was considered as well. All of them was insignificant across gender $(p \geq .05)$.

\subsection{Measures}

2.2.1. Socio-demographic form. The sociodemographic form includes age, educational status, and gender variables. The definition of the trauma which have defined based on DSM V (APA, 2013) was given to participants. Then asked the participants whether they had any prior experience which fits with the definition.

2.2.2. The Positive and Negative Affect Scale (PANAS). The PANAS which was developed by Watson, Clark, and Telegen (1988) to measure general tendencies toward positive affect and negative affect. Different timeframes can supply different scores. In this study, timeframe was their affectivity for 'last 6 months'. Indicating how they feel on general on a 5 point Likert-type scale in the form of from 1 ("very slightly") to 5 ("extremely") were asked from the participants for all 20 items. Turkish adaptation of PANAS was done by Gençöz (2000).

2.2.3. The Social desirability inventory (SDI). The SDI which was originally developed by Stöber (2001) measures the extent that individuals' respond in a favorable manner. Participants were asked to evaluate social desirability by rating 16 dichotomous questions ("true" / "false"). Higher socially desirable responding is shown by higher scores. Scores for social desirability ranged between 0-20 totally. The Turkish version of social desirability inventory which was adapted by Kozan (1983) includes a list of 20 items.

2.2.4. The Responsibility Scale (RS). The Responsibility Scale (RS) which was developed by Topcu (2016; 2018) assess individuals' perceptions about responsibility. Participants were asked to evaluate responsibility by rating on a 5-point Likert-type scale ranging from 0 ("never") to 4 ("always") on 24 items. Inventory has 3 dimensions, namely, emotional, behavioral and cognitive responsibility. Only total score of the scale was used in this study.

2.2.5. The Internal - External Locus of Control Scale (LoC). The LoC was originally developed by Rotter (1966) in order to evaluate the individual's attributions to their consequences of their behaviors. It consists of 29 items and is scaled as dichotomous. Total score ranges from 0 to 23. Personal control, belief in chance, meaningless of the effortfullness, belief in fate and belief in an unjust world are the subscales of the LoC. Participants were asked to evaluate their behaviors by rated on a 5-point Likert-type scale ranging from 1 ("strongly disagree") to 5 ("strongly agree"). The Turkish form of the scale was adapted by Dă̆ (2002).

\subsection{Procedure}

A part of the first author's doctorate thesis is presented in this study (Topcu, 2016). Additionally, part of the data was presented in one of the previous Inpact conference series (Topcu, Köroğlu, \& Gençöz, 2018). A cross-sectional paper-pencil format study was conducted with conveniently sampled 139 participants. For eliminating the sequencing effect instruments in the study were presented in random order. The informed consent and a brief explanation of the study were placed on the first page. The study was approved by the Middle East Technical University Ethical Committee. All statistical analyses were done with the use of IBM SPSS 21. 


\section{Results}

Pearson correlation coefficients were calculated. Results revealed that the Responsibility scale total score was only negatively and significantly correlated with belief in an unjust world $(r=-.24, p<.01)$. Relationship among variables were summarized in Table 1 .

To assess the role of LoC in the prediction of responsibility while controlling the effects of social desirability and positive and negative affect for last six months in a sample of individuals with past traumatic event history, 2-stepped hierarchical regression analysis run. To learn the impact of LoC in the prediction of responsibility, social desirability and positive and negative affect for last six months were entered in the first step; and significantly correlated EMSs with responsibility entered in the second step of the Linear regression analyses (Enter), respectively. In the prediction of responsibility, the first model was significant $(F(3,135)=22.403, p<0.001)$. Only social desirability $(t=6.674 .082, p<.001)$ and PA scores for last six months $(t=3.488, p<.001)$ significantly contributed to the regression. Adjusted $R^{2}$ revealed that both responsibility and PA scores accounted for the variance of responsibility with the proportion of $32 \%$. $\beta$ coefficients showed that exploratory proportions of SD and PA on responsibility were $48 \%$ and $25 \%$, respectively. In the second step of the analyses, only significantly and negatively correlated dimension of LoC, belief in an unjust world, were added. Results revealed that in the prediction of responsibility, the second model was significant $(F(4,134)=18.322, p<0.001)$. SD $(t=6.60, p<.001)$, PA for last six months $(t=3.28, p<.01)$ and belief in an unjust world subscale of $\operatorname{LoC}(t=-2.10, p<.05)$ score significantly contributed to the regression. Adjusted $R^{2}$ revealed that SD, PA for last six months, and belief in an unjust world scores accounted for the variance of responsibility with the proportion of $33 \%$. $\beta$ coefficients showed that exploratory proportions of SD, PA for last six months, and belief in an unjust world on the responsibility were $21 \%, 5 \%$ and $2 \%$, respectively (Table 2 ).

\section{Discussion}

Results revealed that responsibility was only negatively and significantly correlated with belief in an unjust world, which is an external LoC subscale. Also, SD, PA for the last six months and belief in an unjust world scores significantly contributed to the responsibility. In a world where individuals often get what they do not deserve or do not get what they do deserve, responsibility may serve as rationalization and/or coping mechanism (Lench, \& Chang, 2007). Traumatic events are defined as disruptive to the daily routine, develop suddenly and unexpectedly, create horror, anxiety and panic, and disturb the process of making sense of the world (APA, 2013). Individuals with higher anxiety tend to remember more negative events. Easy access to negative events in the memory is related to higher beliefs in an unjust world (Koster, De Raedt, Goeleven, Franck, \& Crombez, 2005). Higher belief in an unjust world is related to greater anxiety, depressive symptoms, neuroticism, and defensiveness (Lench, \& Chang, 2007). Since the sample represents individuals with at least one traumatic event history, it can be concluded that those who believe in less that world is an unjust place may think, feel or act responsibly more which are especially in a socially desirable manner. Thinking, feeling or acting responsibly may be appraised as protective against feelings of failure, guilt or shame, fear of punishment, uncertainty and being victim of an uncontrolled event; ease the escape from the punishment, and prospective and cumulative traumatic effects, and protect themselves against punishment and feelings of guilt, shame, and anger resulted from 'failing' responsibility (Topcu, Köroğlu, \& Gençöz, 2018). Eventually protection and escape may be rewarding. Being rewarding may be related to higher PA for the last six months. On the way through posttraumatic growth, the relationship between belief in an unjust world and responsibility may be influential especially on therapeutic process with individuals with traumatic event history.

Although posttraumatic growth mentioned in this study, it was not assessed any measurement or statistically. It can be considered as a limitation. However, previous literature findings determine the way through posttraumatic growth (Tedeschi \& Calhoun, 1995; 2004). Belief in an unjust world may inhibit individuals from psychological growth (Topcu, Köroğlu, \& Gençöz, 2018) by less likely to cope successfully with their trauma (Lench, \& Chang, 2007) rather than manifesting self-reflective examination, evaluating their behaviors, accepting their emotions, feeling relieved from frightening images of facing emotions, finding peace, contentment, and control over the circumstances, and taking a social role and responsibility (Chandler, 1975; cited in Dawes, Montada, Filipp \& Lerner, 1992).

Limitations were stated previously (Topcu, Köroğlu \& Gençöz, 2018; Topcu, 2016). In this study, only the total score of responsibility was used. However, examining the dimensions of responsibility may lead detailed information about the relationship between responsibility and the LoC. In addition, the assumption which belief in an unjust world could be an inhibitor factor for PTG. This assumption could be tested statistically, too. Further studies can consider these limitations of the current study as well. 
Table 1. Correlations between scale scores $(N=139)$.

\begin{tabular}{|c|c|c|c|c|c|c|c|c|c|c|}
\hline & \multicolumn{2}{|c|}{$\begin{array}{c}\text { Personal } \\
\text { control }\end{array}$} & \multicolumn{2}{|c|}{$\begin{array}{c}\text { Belief in } \\
\text { chance }\end{array}$} & \multicolumn{2}{|c|}{$\begin{array}{c}\text { Meaningless of the } \\
\text { effortfullness }\end{array}$} & \multicolumn{2}{|c|}{$\begin{array}{c}\text { Belief in } \\
\text { fate }\end{array}$} & \multicolumn{2}{|c|}{$\begin{array}{l}\text { Belief in an unjust } \\
\text { world }\end{array}$} \\
\hline & $\boldsymbol{R}$ & $p$ & $\boldsymbol{r}$ & $p$ & $\boldsymbol{r}$ & $p$ & $r$ & $p$ & $r$ & $p$ \\
\hline $\mathbf{R S}$ & -.072 & .397 & .038 & .659 & -.132 & .121 & .067 & .434 & -.243 & $.004 *$ \\
\hline SD & -.157 & .065 & -.082 & .337 & .018 & .829 & .175 & $.039 * *$ & -.102 & .234 \\
\hline PA & -.174 & $.041 * *$ & -.121 & .155 & -.016 & .854 & .052 & .544 & -.122 & .154 \\
\hline NA & -.170 & $.045 * *$ & .166 & .051 & .259 & $.002 *$ & .090 & .291 & .213 & $.012 * *$ \\
\hline
\end{tabular}

Table 2. Linear regression analyses (Enter) with responsibility total score as dependent variable and SD, PA, NA and Belief in an unjust world subscale score of LoC as independent variables.

\begin{tabular}{llccccc}
\hline Model & & \multicolumn{2}{c}{$\begin{array}{c}\text { Unstandardized } \\
\text { Coefficients }\end{array}$} & $\begin{array}{c}\text { Standardized } \\
\text { Coefficients }\end{array}$ & & \\
\cline { 3 - 6 } & & $\mathbf{B}$ & SE & $\boldsymbol{\beta}$ & $\boldsymbol{p}$ \\
\hline Step 1 & SD & 1.156 & .173 & .475 & 6.674 & .000 \\
& PA & .160 & .046 & .246 & 3.488 & .001 \\
& NA & -.063 & .040 & -.110 & -1.545 & .125 \\
Step 2 & SD & 1.132 & .172 & .465 & 6.601 & .000 \\
& PA & .149 & .046 & .230 & 3.275 & .001 \\
& NA & -.045 & .041 & -.080 & -1.114 & .267 \\
& Belief in an Unjust & -.094 & .045 & -.150 & -2.096 & .038 \\
& World & & & & & \\
\hline Step 1: $\mathrm{F}(3,135)=22.403, p<0.001$, Adjusted $\mathrm{R}^{2}=0.318$. Step 2: $\mathrm{F}(4,134)=18.322, p<0.001$, Adjusted $\mathrm{R}^{2}=0.334, \mathrm{R}^{2}$ Change $=0.21$.
\end{tabular}

\section{References}

American Psychiatric Association. (2013). Diagnostic and statistical manual of mental disorders (5th ed.). Arlington, VA: American Psychiatric Publishing.

Dağ, İ. (2002). Kontrol Odağı Ölçeği (KOÖ): Ölçek geliştirme, güvenirlik ve geçerlik çalışması. Türk Psikoloji Dergisi, 17(49), 77-90.

Dawes, R. M., Montada, L., Filipp, S. H., \& Lerner, M. J. (1992). Life crises and experiences of loss in adulthood.

Gençöz, T. (2000). Pozitif ve negative duygu ölçeği: Geçerlik ve güvenirlik çalışması. [Positive and Negative Affect Schedule: A study of validity and reliability] Turkish Journal of Psychology, 15(46), 19-26.

Koster, E. H. W., De Raedt, R., Goeleven, E., Franck, E., \& Crombez, G. (2005). Mood congruent attentional bias in dysphoria: Maintained attention to and impaired disengagement from negativeinformation. Emotion, 5, 446-455.

Kozan, K. (1983). Davranış bilimleri araştırmalarında sosyal beğenirlik boyutu ve Türkiye için bir sosyal beğenirlik ölçeği. ODTÜ Gelişme Dergisi, 10(3), 447-478.

Lazarus, R. S., \& Folkman, S. (1984). Stress, appraisal, and coping. New York: Springer Publishing Co.

Lench, H. C., \& Chang, E. S. (2007). Belief in an unjust world: When beliefs in a just world fail. Journal of Personality Assessment, 89(2), 126-135.

Rotter, J. B. (1966). Generalized expectancies for internal versus external control of reinforcement. Psychological monographs: General and applied, 80(1), 1.

Stöber, J. (2001). The Social Desirability Scale-17 (SDS-17): Convergent validity, discriminant validity, and relationship with age. European Journal of Psychological Assessment, 17(3), 222.

Tedeschi, R. G., \& Calhoun, L. G. (1995). Trauma \& transformation: Growing in the aftermath of suffering. Thousand Oaks, CA: Sage Publications.

Tedeschi, R. G., \& Calhoun, L. (2004). Posttraumatic growth: Conceptual foundations and empirical evidence. Psychological Inquiry, 15, 1-18. 
Topcu, M. (2016). The Concept of Gratitude and its Relationship with Posttraumatic Growth: Roles of Early Maladaptive Schemata and Schema Coping Styles, Locus of Control and Responsibility (Unpublished Doctoral dissertation). Retrieved from http://etd.lib.metu.edu.tr/upload/12619691/index.pdf

Topcu, M., Köroğlu, D. \& Gençöz, F. (2018) The Role of Schemata in Responsibility among People with Traumatic Event History. In Inpact: Psychological Applications and Trends, (p. 68-72), Porto, Portugal.

Topcu, M., Öge, B. \& Gençöz, F. (2018). Psychometric properties of the Responsibility Scale, Ankara University the Journal of the Faculty of Languages and History-Geography, 58(1), 1056-1078.

Watson, D., Clark, L. A., \& Tellegen, A. (1988). Development and validation of brief measures of positive and negative affect: the PANAS scales. Journal of personality and social psychology, 54(6), 1063. 